\title{
Pengaruh Diabetes Melitus Terhadap Tajam Penglihatan
}

\author{
Sudirman \\ Email: sudirman@uniqhba.ac.id \\ Dosen Prodi Pendidikan Matematika FKIP UNIQHBA
}

\begin{abstract}
ABSTRAK
Penurunan tajam penglihatan selain dipengaruhi oleh katarak juga disebabkan oleh penyakit yang mempengaruhi retina. Diabetes adalah penyakit yang mempengaruhi retina. Penduduk di wilayah Puskesmas Kopang memiliki keadaan sosial ekonomi dan tingkat pendidikan yang masih rendah. Penelitian ini bertujuan untuk mengetahui pengaruh diabetes mellitus terhadap tajam penglihatan. Penelitian ini dilakukan di Puskesmas Kopang, Lombok Tengah mulai April sampai Mei 2018. Rancangan penelitian adalah cross sectional dengan jumlah sampel 73 responden yang berumur 40 tahun keatas yang diambil secara simple random sampling. Pengukuran tajam penglihatan menggunakan Tumbling E, untuk menentukan diabetes dilakukan pengukuran glukosa darah sewaktu ( $\geq 200 \mathrm{mg} / \mathrm{dl}$ ) dengan Accu Check Active untuk mengetahui signifikasi data di analisis menggunakan uji Mann - Whitney menggunakan program SPSS versi 16.0 dengan tingkat kepercayaan 95\% $(\alpha=0.05)$. Berdasarkan hasil analisis statistik, diabetes mellitus berpengaruh secara signifikan $(0.00<0.05)$ terhadap tajam penglihatan yaitu sebesar $42.5 \%$, artinya diabetes mellitus menyebabkan terjadinya penurunan tajam penglihatan sebesar $42.5 \%$.
\end{abstract}

Kata Kunci: Diabetes Mellitus, Tajam Penglihatan

\begin{abstract}
Low vision affected by cataracts is also caused by retina disease. Diabetes is a disease that affects the retina. The population in the Kopang Health Center area has low of socioeconomic and education. The aim of this study was to evaluate the influence of diabetes mellitus to visual acuity. This study is non experimental with cross-sectional method and was carried out involving 73 respondents as sample aged 40 years, who were taken by simple random sampling in Kopang Primary Health Care, Central Lombok. Statistical analysis shows, this study revealed that the diabetes mellitus was significantly $(\mathrm{P}<0.05)$ influenced to visual acuity was equal to $42.5 \%$, it mean that diabetes mellitus was found in $42.5 \%$ of those with low vision.
\end{abstract}

Keywords: Diabetes Mellitus, Visual Acuity

\section{A. LATAR BELAKANG}

Pemeriksaan tajam penglihatan merupakan pemeriksaan fungsi mata. Gangguan penglihatan memerlukan pemeriksaan untuk mengetahui sebab kelainan mata yang mengakibatkan turunnya tajam penglihatan. Untuk mengetahui tajam penglihatan seseorang dapat dilakukan pengukuran dengan menggunakan kartu Snellen (Snellen Chart) atau tumbling $E$ [1]. Penyebab tersering turunnya tajam penglihatan adalah katarak, parut kornea yang mempengaruhi jalur penglihatan dan penyakit-penyakit yang mempengaruhi retina [2]. Degenarasi makular, diabetes [2] dan hipertensi [3] adalah penyakit yang bisa mempengaruhi retina. Pekerjaan yang banyak terpapar sinar matahari mengakibatkan terkena sinar ultraviolet [4], sinar ultraviolet diperkirakan mempengaruhi ketajaman penglihatan. 
Diabetes Mellitus (DM) adalah salah satu penyakit yang diperkirakan mempercepat proses turunnya tajam penglihatan, karena DM dapat mempengaruhi kejernihan lensa akibat peningkatan kadar gula darah dalam lensa [5]. Selain pada lensa, diabetes mellitus juga dapat menimbulkan komplikasi pada retina yang disebut retinopati diabetik, retinopati diabetik mengakibatkan terjadi kerusakan pembuluh darah retina atau lapisan saraf mata sehingga mengalami kebocoran. Akibatnya, terjadi penumpukan cairan (eksudat) yang mengandung lemak serta pendarahan pada retina [6].

Selain diabetes, hipertensi diperkirakan menjadi salah satu penyebab turunnya tajam penglihatan. Hipertensi atau darah tinggi dialami hampir sebagian besar penderita diabetes, hipertensi merupakan salah satu komplikasi dari diabetes, diperkirakan muncul menyertai komplikasi lainnya yaitu turunnya tajam penglihatan. Retina merupakan bagian tubuh yang secara langsung bisa menunjukkan adanya efek dari hipertensi terhadap arteriola (pembuluh darah kecil).

Faktor lainnya yang diperkirakan bisa memicu terjadinya turunnya tajam penglihatan adalah pekerjaan, yaitu pekerjaan di luar ruangan yang memungkinkan lebih sering terkena paparan sinar matahari. Pekerjaan seseorang yang banyak terpapar sinar matahari seperti petani, nelayan dan buruh lebih berisiko terkena penurunan tajam penglihatan [7]. Hasil penelitian Ziahulhak [4] di Kalimatan Timur menunjukkan bahwa, pekerjaan dan aktifitas memiliki hubungan yang secara statistik bermakna dengan katarak, yang ditandai dengan turunnya ketajaman penglihatan (low vision).

Topografi wilayah Puskesmas Kopang terdiri dari, lereng/bukit, dan dataran, mayoritas pekejaannya sebagai petani $(42.79 \%)$, persentase penduduk miskin (pra sejahtera) sebesar $37.41 \%$ dan $41.83 \%$ penduduknya belum pernah sekolah atau tidak tamat Sekolah Dasar (SD) [8] dan prevalensi katarak di Lombok sebesar 11.6\% [9]. Data diatas menggambarkan bahwa penduduk disekitar
Puskesmas Kopang memiliki keadaan sosial ekonomi dan tingkat pendidikan yang masih rendah, hal inilah yang menyebabkan kurangnya akses informasi dan pengetahuan kesehatan pada masyarakat, sehingga akan menimbulkan ketidakberdayaan dan ketidaktahuan masyarakat tentang kesehatan mata.

Puskesmas Kopang merupakan salah satu dari 2 (dua) puskesmas yang ditunjuk oleh pemerintah pusat dan daerah melalui Dinas Kesehatan NTB yang bekerjasama dengan Helen Keller Internasional untuk dijadikan proyek percontohan diselenggarakannya kegiatan operasi mata sejak tahun 2005. Pada tahun 2008 dari 1739 pasien yang memeriksakan diri di Puskesmas Kopang, 1464 orang dinyatakan positif menderita katarak, sebanyak $35.60 \%$ ditunda operasinya karena menderita diabetes dan $31.81 \%$ karena hipertensi. Hal ini berarti, tingginya angka kejadian katarak diatas diduga disebabkan oleh penyakit diabetes mellitus dan hipertensi.

Berdasarkan uraian diatas, penurunan tajam penglihatan selain dipengaruhi oleh katarak juga disebabkan oleh penyakit yang mempengaruhi retina, diabetes dan hipertensi adalah penyakit yang mempengaruhi retina. Selain itu juga pekerjaan yang banyak terpapar sinar matahari, juga diperkirakan mempengaruhi tajam penglihatan. Penduduk di wilayah Puskesmas Kopang memiliki keadaan sosial ekonomi dan tingkat pendidikan yang masih rendah, hal ini akan menyebabkan kurangnya akses informasi dan pengetahuan tentang kesehatan mata sehingga gangguan penyakit mata akan meningkat.

Tujuan dari penenilitian ini adalah untuk mengetahui pengaruh diabetes mellitus, hipertensi, interaksi diabetes mellitus dan hipertensi serta mengetahui pengaruh pekerjaan terhadap tajam penglihatan di Puskesmas Kopang. Hasil penelitian ini diharapkan Bagi masyarakat, dapat memberikan sumbangan pengetahuan, sehingga dapat dimanfaatkan dalam upaya pencegahan penurunan tajam penglihatan sedini mungkin di masyarakat. 


\section{B. METODE PENELITIAN}

\section{Rancangan Penelitian}

Rancangan penelitian ini adalah penelitian potong lintang (cross sectional) dengan sistem simple random sampling single proportion.

\section{Populasi dan Sampel Penelitian}

Populasi penelitian ini adalah seluruh pasien yang melakukan pemeriksaan mata di Puskesmas Kopang Lombok Tengah pada tahun 2017, yakni sebesar 343 orang dengan jumlah sampel 73 responden yang berumur 40 tahun keatas.

\section{Tempat dan Waktu Penelitian}

Penelitian ini dilakukan di Puskesmas Kopang Kabupaten Lombok Tengah dan berlangsung dari bulan April 2018 sampai Mei 2018.

\section{Tehnik pengumpulan data}

a. Mencatat identitas subyek penelitian, meliputi nama, alamat dan usia serta dilakukan pengisian formulir penelitian secara lengkap sesuai alur penelitian yang telah ditentukan.

b. Meminta responden untuk menutupi bagian mata kirinya (Ocular Sinistra) dengan menggunakan telapak tangan kirinya tetapi jangan ditekan. Memposisikan telapak tangan responden seolah-olah memegang telur dalam genggamannya kemudian tekapkan ke bagian mata yang akan di tes terlebih dahulu.

c. Menggunakan tali untuk mengukur 6 meter yang memiliki simpul dibagian tengah (jarak 3 meter) kemudian mempersilahkan responden untuk duduk atau berdiri dengan jarak 6 meter berhadapan dari tempat petugas lapangan. Posisi responden yang duduk atau berdiri harus membelakangi matahari atau cahaya (tidak menyilaukan mata responden).

d. Menjelaskan bahwa responden harus menunjukkan arah sesuai dengan arah simbol E tersebut (ke atas, ke bawah, ke kiri atau ke kanan). Tumbling E ini dibuat selain untuk orang yang bisa membaca juga untuk orang yang tidak bisa membaca, karena cukup memberitahu arah kaki dari huruf $\mathrm{E}$ tersebut

e. Responden dikatakan bisa menjawab dengan benar jika responden sanggup menjawab 4 pertanyaan dengan benar secara berturutturut atau jika responden sanggup menjawab 5 dari 6 pertanyaan dengan benar, atau jika responden sanggup menjawab 6 dari 8 pertanyaan dengan benar [10].

f. Jika responden bisa menjawab benar pada jarak 6 meter dengan ukuran tumbling $\mathrm{E}$ kecil (18) maka ukuran visus (ketajaman penglihatan) responden adalah 6/18. Tetapi apabila tidak memenuhi kriteria benar diatas dilanjutkan dengan pengukuran visus $6 / 60$.

g. Jika responden bisa menjawab benar pada jarak 6 meter dengan ukuran tumbling $\mathrm{E}$ besar (60) maka ukuran visus (ketajaman penglihatan) responden adalah $6 / 60$, tetapi Jika responden tidak dapat melihat huruf $\mathrm{E}$ besar (60) dari jarak 6 meter, maka peneliti harus maju ke jarak 3 meter dan melakukan tes ketajaman penglihatan dengan huruf $\mathrm{E}$ besar (60).

h. Jika responden bisa menjawab benar pada jarak 3 meter dengan ukuran tumbling $\mathrm{E}$ besar (60) maka ukuran visus (ketajaman penglihatan) responden adalah $3 / 60$, tetapi Jika responden tidak dapat melihat huruf $\mathrm{E}$ besar (60) dari jarak 3 meter, maka peneliti harus maju ke jarak 1 meter dan melakukan tes ketajaman penglihatan dengan huruf $\mathrm{E}$ besar (60) atau melakukan tes menghitung jari.

i. Jika responden bisa menjawab benar pada jarak 1 meter dengan ukuran tumbling $\mathrm{E}$ besar (60) atau bisa menjawab benar dengan menghitung jari maka ukuran visus (ketajaman penglihatan) responden adalah $1 / 60$, tetapi Jika responden tidak dapat melihat huruf E besar (60) atau menghitung jari dari jarak 1 meter, maka peneliti harus melakukan tes persepsi cahaya untuk mengetahui reaksi pupil responden dengan menggunakan senter, caranya dengan 
mengarahkan cahaya senter dari atas, bawah, kiri dan kanan.

j. Jika responden bisa menjawab benar arah senter setelah dilakukan tes reaksi pupil, maka ukuran visus responden adalah PL(+) (Positif Perception Light). Tetapi apabila tidak bisa menjawab benar arah senter setelah dilakukan tes reaksi pupil, maka ukuran visus responen adalah PL (-) (Negatif Perception Light). Biasanya kalau ukuran visus responden PL (-) diperkirakan sarafnya sudah rusak, sehingga sulit disembuhkan.

k. Bila pengukuran visus untuk melihat reaksi pupil sudah selesai maka dilanjutkan pengukuran visus untuk mata kanan (Ocular Dextra).

1. Jika ditemukan visus kurang dari $6 / 18$ maka responden tersebut diperkirakan mengalami penurunan ketajaman penglihatan.

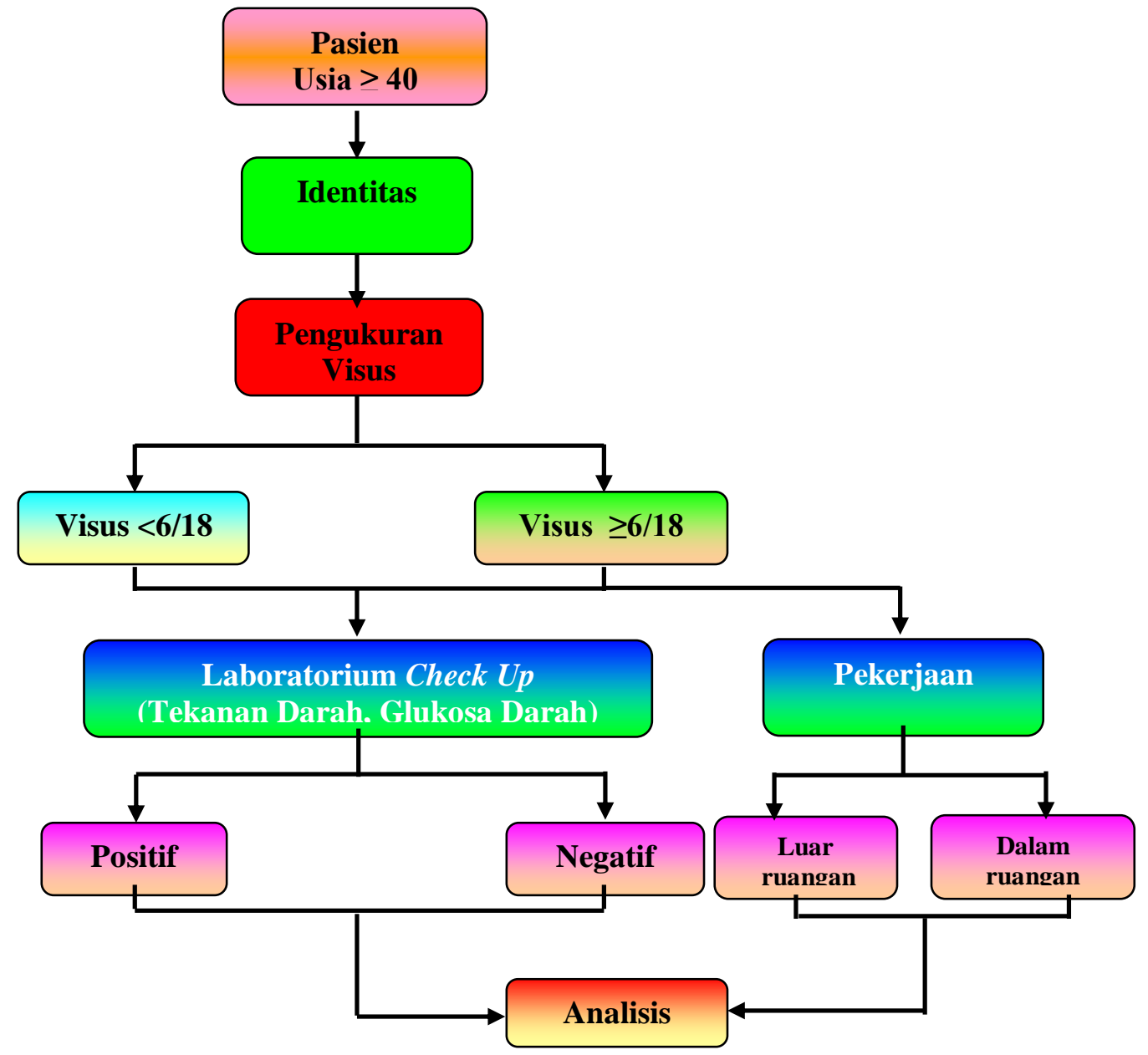

Gambar 1. Alur Penelitian m. Setelah pengukuran visus selesai, selanjutnya dilakukan tes laboratorium untuk memeriksa glukosa darah dan Tekanan darah. Tekanan darah diukur pada posisi duduk sebanyak tiga kali pengukuran pada rentang 10 menit.

\section{Analisa Data}

Hasil penelitian diuji dengan Mann Whitney test yang merupakan uji alternatif dari uji $t$ - test independent jika distribusi data tidak normal. Pengolahan dan analisa data menggunakan bantuan program SPSS versi 16.0 dengan tingkat kepercayaan 95\% ( $\alpha=0.05)$.

\section{Alur Penelitian}

Alur penelitian ditunjukkan oleh Gambar 1. 


\section{HASIL DAN PEMBAHASAN}

\section{Pengaruh Diabetes Mellitus Terhadap Tajam penglihatan}

Uji statistik mengenai diabetes mellitus dengan tajam penglihatan ternyata berpengaruh secara signifikan $(\mathrm{p}<0.05)$ dengan Odd Ratio $(O R)=20.667$ dan Confidence Interval $(C I)=$ 5.308-80.464, artinya responden yang menderita diabetes besar kemungkinannya mengalami resiko penurunan tajam penglihatan, dalam penelitian ini ditemukan responden yang mengalami diabetes mellitus mengalami penurunan tajam penglihatan sebesar $42.5 \%$ (Gambar 2).

Hasil penelitian ini diperkuat oleh penelitian Bener, et.al., [11] yang dilakukan di Doha Qatar pada umur 50 tahun keatas dengan sampel 96.348 orang, ditemukan diabetes tipe 2 beresiko mengalami low vision (resiko relatif $=1.32$ dengan interval kepercayaan (CI) $95 \%$ =1.13-1.54). Hampir setengah dari responden yang mengalami low vision menderita diabetes mellitus (44.7\%), sehingga menyimpulkan diabetes mellitus tipe 2 secara signifikan berpengaruh terhadap turunnya tajam penglihatan (low vision).



Gambar 2. Grafik Diabetes Dengan Tajam Penglihatan

Lebih lanjut penelitian Khandekar [12] pada 350 responden di Oman, ditemukan prevalensi terjadinya diabetes mellitus sebesar $55 \%$ dan berhubungan secara signifikan terhadap katarak, katarak merupakan salah satu penyebab turunnya tajam penglihatan (CI 95\%=49.6-60.1). Rata - rata umur pada diagnosa pertama menderita diabetes mellitus pada umur 44 tahun (SD = 12.6 tahun), 184 responden (52\%) menderita diabetes lebih dari 10 tahun. Penelitian Idil, et.al. [13], menilai prevalensi yang berhubungan dengan penurunan tajam penglihatan (low vision) akibat diabetes mellitus telah diperiksa responden yang berumur 30 tahun keatas yang dilakukan di Turki dengan populasi 96.348 orang. Hasilnya diabetes mellitus menyebabkan turunnya tajam penglihatan sebesar (42\%).

Adanya pengaruh yang erat antara diabetes dengan tajam penglihatan karena diabetes dapat mempengaruhi kejernihan lensa, diabetes akan meningkatkan kadar glukosa pada aqueous humor kemudian akan masuk secara difusi ke dalam lensa, sehingga kadar glukosa dalam lensa akan meningkat, beberapa molekul glukosa akan diubah menjadi sorbitol oleh enzim aldose reduktase yang tidak dimetabolisme namun menetap di dalam lensa [5]. Selanjutnya, tekanan osmotik akan menyebabkan influks air ke dalam lensa yang menyebabkan pembengkakan dari serat-serat lensa akibat hidrasi cairan sehingga bisa menyebabkan kekeruhan pada lensa, selain itu juga dapat mempengaruhi kemampuan/kekuatan refraksi lensa, serta dapat menyebabkan akomodasi yang menurun, akibatnya terjadi penurunan tajam penglihatan [5].

Dalam penelitian ini responden yang mengalami diabetes mellitus diperkirakan mengalami penyakit retinopati diabetes, hal ini berdasarkan dari 34 responden yang menderita diabetes, $55.9 \%$ mengalami diabetes mellitus selama $\geq 5$ tahun, dan menyebabkan terjadinya sepenurunan tajam penglihatan sebesar $52,9 \%$, dalam penelitian ini juga ditemukan kebanyakan responden sudah menderita diabetes mellitus selama 6 tahun (26.5\%), tetapi tidak melakukan diagnosa tejadinya diabetik retinopati.

Penelitian Bener et.al., [11] menemukan, diabetes retinopati berpengaruh terhadap tajam 
penglihatan $(\mathrm{OR}=1.71 ; \mathrm{CI}=1.39-2.10)$. Lebih lanjut Khandekar, et.al. [12] menyatakan, angka kejadian retinopati diabetes dipengaruhi tipe dan durasi penyakit diabetes melitus (DM). Pada DM tipe I (insulin dependent atau juvenile DM ), yang disebabkan oleh kerusakan sel beta pada pankreas, umumnya responden berusia muda (kurang dari 30 tahun), retinopati diabetes ditemukan pada 13 persen kasus yang sudah menderita DM selama kurang dari 5 tahun, yang meningkat hingga 90 persen setelah DM diderita lebih dari 10 tahun. Pada DM tipe 2 (non-insulin dependent DM), yang disebabkan oleh resistennya berbagai organ tubuh terhadap insulin (biasanya menimpa usia 30 tahun atau lebih), retinopati diabetes ditemukan pada 2440 persen responden penderita DM kurang dari 5 tahun, yang meningkat hingga 53-84 persen setelah menderita DM selama 15-20 tahun. Rata - rata umur yang mengalami Retinopati diabetes (DR) selama 54 tahun ( $\mathrm{SD}=11$ tahun). 184 orang $(52 \%)$ menderita diabetes lebih dari 10 tahun. Sebuah penelitian di Iran pada responden dengan Noninsulin Dependent Diabetes Mellitus (NDDM) dengan lama menderita diabetes selama 6.9 tahun, ditemukan angka terjadinya DR sebesar 8.9\% [14]. Analisis dengan regresi logistic menunjukkan bahwa low vision karena retinopati diabetes disebabkan menderita diabetes selama $\geq 15$ tahun [13]. Lebih lanjut Khandekar (2003) melakukan penelitian di Oman pada 350 responden yang menderita diabetes mellitus selama $\geq 15$ tahun, ditemukan sebanyak 101 (29\%) responden mengalami retinopati diabetes .

Papente [15] menyatakan, komplikasi diabetes mellitus pada mata dapat terjadi berupa retinopati diabetes. Retinopati diabetes merupakan komplikasi yang sering dijumpai pada penderita diabetes mellitus menahun. Retinopati diabetes dapat menyebabkan gangguan penglihatan dari yang ringan sampai kebutaan. Di Amerika Serikat diabetes mellitus merupakan penyebab utama terjadinya gangguan penglihatan, kira-kira 5000 kasus gangguan penglihatan terjadi tiap tahun akibat penyakit ini dengan tajam penglihatan 20/200 (6/60) atau lebih buruk [15].

Hasil penelitian ini diperkirakan merupakan jenis diabetika renitopati nonproliferatif karena hasil penelitian menunjukkan kebanyakan telah terjadi diabetes selama 6 tahun, hal ini sesuai dengan pernyataan Papente [15] bahwa, diabetika nonproliferatif didasarkan atas adanya riwayat sakit diabetes pada penderita yang sudah berlangsung sejak 6 tahun yang lalu, dengan gula darah yang tidak terkontrol, lebih lanjut Papente [15] menambahkan, terdapat beberapa faktor yang mempengaruhi terjadinya retinopati diabetes yaitu lamanya diabetes mellitus, semakin lama diabetes diderita, lebih besar kemungkinan timbulnya retinopati diabetes. Dikatakan setelah 7 tahun menderita diabetes, maka $50 \%$ penderita akan mengalami retinopati diabetes.

Faktor lain yang dapat mempengaruhi terjadi retinopati diabetes ini adalah kontrol terhadap diabetes mellitusnya. Pengawasan yang baik mengurangi frekuensi atau memperlambat timbulnya retinopati diabetes. Terutama bila pengawasan yang baik ini dilaksanakan pada tahun-tahun pertama membawa pengaruh baik yang lebih besar. Dari hasil penelitian ternyata bahwa frekuensi retinopati pada penderita diabetes dengan pengawasan yang baik yaitu $36-38 \%$, sedangkan penderita yang tidak mendapat pengawasan yang baik mencapai 50-60\% [15].

Penurunan tajam penglihatan akibat retinopati diabetes dihubungkan dengan edema makular, perdarahan vitreous yang mengaburkan media ocular. Kebocoran kapiler retina akan menyebabkan edema makular dan diketahui secara klinis kebocoran ini menyebabkan gangguan penglihatan. Dari perspektif optik, sista makular menghamburkan cahaya yang masuk ke retina sehingga tidak bisa fokus ke fotoreseptornya, akibatnya tejadi penurunan kualitas penglihatan. Dari bahasan seluler, fungsi penglihatan akan menurun jika cairan terakumulasi dalam retina, sehingga 
mengubah konsentrasi ion ekstraseluler dan secara fisik menekan neuron retina, akibatnya neuron semakin lemah [6] dan mempengaruhi tajam penglihatan.

\section{KESIMPULAN}

Berdasarkan hasil dan pembahasan dapat disimpulkan bahwa diabetes mellitus berpengaruh secara signifikan terhadap tajam penglihatan yaitu mengalami penurunan tajam penglihatan sebesar $42.5 \%$.

\section{DAFTAR PUSTAKA}

[1] Fitriani, D.G., 2009. Tingkat Kepuasan Pasien Setelah Operasi Katarak Dengan Metode SICS di Lombok. Tesis. Program Studi Ilmu Penyakit Mata, Fakultas Kedokteran, Universitas Indonesia. Jakarta.

[2] Guyton AC, Hall JE., 1996. Mata I. Sifat Optik Mata. Dalam: Guyton AC, penyunting. Buku Ajar Fisiologi Kedokteran edisi 9. Jakarta; Penerbit buku Kedokteran EGC; 779.

[3] Ocampo V, 2008. Cataract, Senile. (Online) Available on: http://www.emedicine.com/oph/. [Accessed: 2009 December 25].

[4] Ziahulhak, S.R., 2007. Asosiasi katarak dan Pterygium di Kalimantan Timur. Tesis. Program Studi Ilmu Penyakit Mata, Fakultas Kedokteran, Universitas Indonesia. Jakarta.

[5] Rosenfeld S. and Blecher MH., 2006. Anatomy. In: Rosenfeld S, editors. Lens \& Cataract. 2006-2007. San Fransisco; American Assosciation of Ophtalmology; 2006.

[6] Antonetti1 DA, Alistair JB, Sarah KB, Willard MF, Thomas WG, Leonard SJ, Mark K, Scot RK, Kyle K, Kathryn FL, Christopher CN, Patrick GQ, Lakshman S, Ian AS., 2006. Retinopaty Diabetic. (Online)

(http://kireihimee.blogspot.com/retinopati -diabetes-jurnal.html). Diakses: 25 Januari 2010.

[7] Sitompul, R., 2009. Mata. (Online) (http://rohmatul- umah.blog.friendster.com). Diakses : 25 Januari 2010.

[8] BPS, 2008. Badan Pusat Statistik Kecamatan Dalam Angka Dalam Angka. Mataram.

[9] Agustiawan R. 2006. Prevalensi katarak senilis dan hubungannya dengan indeks massa tubuh di pulau Lombok. Tesis. Program Studi Ilmu Penyakit Mata, Fakultas Kedokteran, Universtias Indonesia. Jakarta.

[10] Limburg H., 2004. Manual for Rapid Assessment of Cataract Surgical Services. WHO Prevention of blindness and deafness; Switzerland.

[11] Bener, A., Huda S. A., Fareed A. W., Sara M. D., 2006. Risk Factors for Low Vision in Elderly People in a Rapidly Developed Society. Asian J Ophthalmol. 10:126-129., (Online) (www.seagig.org). Accessed, 22 January 2010

[12] Khandekar, R.B., Mahfouth A. B., Abdallah A. G., 2009. Diabetic retinopathy, visual impairment and ocular status among patients with diabetes mellitus in Yemen: A hospital-based study. indian J Ophthalmol. Jul-Aug; 57(4): 293-298.

[13] Idil, A., Caliskan, D., Ocaktan, E., 2004. The prevalence of blindness and low vision in older onset diabetes mellitus and associated faktors: A community-based study. European Journal of Ophthalmology. 2004, vol. 14, nº , pp. 298. (Online). (http://cat.inist.fr/?aModele=afficheN\&cp

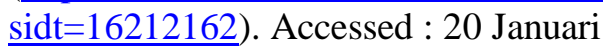
2010

[14] Gunaid AA., Hummad NA., Tamim KA., 2004. Consanguineous marriage in the capital city Sana'a, Yemen. J Biosoc Sci. 36:111-21.

[15] Papente, D., 2009b. Retinopati Diabetika. Online (http://dianpapente.blogspot.com). Accessed : 20 Januari 2010. 